\title{
On Architecture as a Spatial Art
}

\author{
Andrea Sauchelli
}

\begin{abstract}
A в STRACT I present and evaluate various criticisms against the view that architecture and architectural value are to be understood solely in terms of internal space. I conclude that the architectural value of a building should not be limited to its internal spatial effects because the value of other elements, such as (non-spatial) function, materials, ornamentation, and so on cannot all be reduced to spatial values.

KEY WORDS Architecture, Space, Ornament, Roger Scruton, Bruno Zevi, Aesthetic Value
\end{abstract}

The idea of a connection between architecture and space is intuitive and has appealed to many architects and art critics. ${ }^{1}$ After all, the function of architecture seems to be 'to create places and contexts in which social life goes on.' ${ }^{2}$ Space has also been taken as the proper medium of architecture as an art. ${ }^{3}$ However, the nature of the relation between architecture and space raises a number of philosophical questions. Can we define architecture in terms of space? Are architectural value and architectural understanding related to space? What conception of space is at issue in this relation? One influential view, suggested by Bruno Zevi, is that space is essential for both the definition and appreciation of architecture. In what follows, I first present two naive definitions of architecture in terms of space and then introduce and clarify Zevi's view. I then present a number of objections to the view that have been raised by Roger Scruton and add critical remarks of my own. Finally, I argue that considerations of space in the experience, definition, and evaluation of architecture are certainly important, but that space cannot be taken as the principal and fundamental parameter of architectural value.

\section{Space and the Essence of Architecture}

The concept of space can be related to a general definition of architecture, to what constitutes the success of an architectural design, to a general conception of architectural experience, to architectural value, and so on. As may be surmised, all these concepts are interconnected.

A first rough definition of architectural art in terms of space runs as follows:

(D1) Something is an architectural work of art if, and only if, the content of an appropriate experience of it, as what it is, necessarily includes an experience of space. 
Taken literally, this definition seems false and not interesting. The mere experience of space is clearly not sufficient for something to be a work of architecture. Standing in an open field or climbing a mountain involves an experience of space, but open fields and mountains are not works of architecture. The main problem of D1 is that it does not seem to account for the existence of basic architectural elements: walls, roofs and so on. Di can be qualified and improved:

(D2) Something is an architectural work of art if, and only if, the content of an appropriate experience of it, as what it is, necessarily includes an experience of enclosed space.

According to this definition, the key concept for a definition of architecture is not space as such, but rather enclosed space. ${ }^{4}$ However, D2 does not seem to capture other essential elements of what we appreciate in buildings qua works of architecture. More specifically, as Scruton claims regarding a similar definition, it does not take into account such important features as effects of light and shade, ornament, function, texture, and mouldings. These elements can hardly be excluded from the appreciation of a building; hence, they need to be accommodated in a definition of architecture. ${ }^{5}$

Zevi defined architecture in terms of a conception of space that also includes an account of these other elements. He distinguished two kinds of space: the internal and the external (or urban) space. The former is completely determined by the building itself, while the latter is determined by a particular building and its surroundings. ${ }^{6}$ According to him, only the former is relevant to a judgement of architectural success. In his clarification of the concept of space, Zevi relied on Sigfried Giedion's interpretation of the history of architecture as a succession of different spatial conceptions. ${ }^{7}$ Without going into unnecessary detail, Giedion and Zevi argued, among other things, that Cubism is a crucial point in the development of the conception of space in art. According to them, Cubism breaks with traditional perspective in the sense that, for example, Picasso and Braque represent objects from several perspectives at once, instead of from a simple privileged point of view, in contrast to what had been done before them. ${ }^{8}$ Giedion also claimed that the Cubist representation of objects, characterized by the simultaneous presence of several points of view, somehow introduced into the consciousness of modern man something that was suggested in the emerging scientific discoveries of Albert Einstein: simultaneity. ${ }^{9}$ Leaving aside fanciful connections between Cubism and the Theory of Relativity, what is meant here is simply that the so-called dimension of space cannot be fully appreciated without taking into account a 
temporal element, that is, the time required to explore the internal space of the building. In other terms, in order to appreciate the internal space of a building, we need time to move inside it. ${ }^{10}$ This temporal aspect of the perception of space implies a multiplicity of different spatial experiences generated by the same building: the possible paths taken by different observers to explore, for example, a medieval church can always be different from each other. Summing up, Zevi suggested that the conception of space that is relevant to architecture is of an internal space that requires movement (and direct acquaintance) to be perceived and appreciated.

In addition to having offered a clarification of the notion of space, Zevi showed himself to be aware of the difficulties faced by D1 and D2. For instance, against $\mathrm{D}_{1}$, he denied that the spatial value of a building is its sole value and acknowledged that a work of architecture can be evaluated from different perspectives. However, he also claimed that, if we want to value a building from an architectural point of view, the spatial aspect is to be taken as a frame of reference against which other elements can be understood. In other words, we should always refer to the spatial value when we evaluate a building even from different points of view, if we want to understand its architectural value. ${ }^{11}$ More specifically, Zevi claimed that, even though details, ornament, function, and so on are criteria of evaluation, they cannot be considered as independent from their spatial value: their architectural value is always to be understood in terms of the spatial value they have in the context of the building. For example, the ornamentation (and other non-spatial features) should be considered as relevant to the architectural value of a building to the extent that it provides a better clarification or experience of its spatial effect. Similarly, the architectural value of other kinds of detail should be understood in terms of the role they play in determining the spatial effect of the composition. What is proper and central in an architectural work of art is a meaningful creation of space through limitations, and other features should be understood, if relevant to an architectural evaluation, as details that influence the spatial value of the composition.

In light of the foregoing, we may present the following definition of architecture:

(DZ) Something is an architectural work of art if, and only if, the content of an appropriate experience of it, as what it is, necessarily includes an experience of internal space (in the defined sense), and its other elements (ornamentation, lighting, materials, and so on) promote the spatial effect via a process of meaningful limitations. ${ }^{12}$ 
Architectural success (or beauty) is to be seen in terms of how the internal space affects us: 'Beautiful architecture would then be architecture in which the internal space attracts us, elevates us and dominates us spiritually. No work lacking internal space can be considered architecture. ${ }^{\prime 13}$ An architectural judgement, that is, a judgement on a building as a work of architecture, is fundamentally a judgement about its internal space (as previously defined). ${ }^{14}$ The overall value of a building is not to be reduced to its spatial value; however, the architectural value of a building must be assessed in relation to its spatial value. ${ }^{15}$

\section{Objections}

According to DZ, the details of a building have an architectural interest to the extent that they emphasize or clarify spatial elements. For instance, an internal cornice in St Peter's has architectural value because 'it brings the space of the wall to an effective conclusion, and defines thereby the hidden geometry of the roof cavity'. ${ }^{16}$ The above elaboration of Zevi's remarks on architecture in terms of space succeeds if it shows that each detail of an architectural composition can be seen as having a bearing on the internal space of the building. In this section, I will first introduce, elaborate and evaluate Scruton's objections to this account and then advance other criticisms.

Scruton's first objection to Zevi's account is based on the nature of the builder's material. Scruton claims that certain works of architecture would lose their architectural significance if they had been built using materials other than those from which they were actually constructed. For example, the colonnades at St. Spirito in Florence would lose architectural significance if they had been built in wood or granite, instead of pietra serena (grey sandstone or serene stone). The point is that the materials from which an architectural work is constructed influences the value, experience, and judgement of it qua work of architecture and this influence cannot be thought of as being merely a function of the spatial effect that different materials have on the perceiver. Suppose that the spatial effect of the colonnades at St. Spirito would be unaffected by the substitution of its colonnades in pietra serena with a similar material. According to Scruton, the resulting architectural experience would be deprived of the aesthetic pleasure derived from the beauty of the original material; hence, the particular technical choice of a specific material should be considered as aesthetically relevant.

We may also add that, in virtue of our knowledge of the particular significance that pietra serena has in the history of architecture in Tuscany, 
the material from which the colonnades of St. Spirito were constructed is an element of architectural interest because awareness of its significance affects and possibly enhances the architectural experience of the work. This enhancement cannot be understood in purely spatial terms and has a clear aesthetic and artistic relevance. Therefore, the material is significant for the architectural value of a work and this value is not prima facie related to space.

This objection, which was not advanced by Scruton, requires other premises. For instance, it presupposes a notion of architectural experience and appreciation (or, more generally, of aesthetic experience and appreciation) according to which knowledge of relevant background features of a work of art influences its related experience and appreciation. ${ }^{17}$ This view is accepted by many contemporary philosophers of art and does not constitute a prima facie reason to resist the argument. The foregoing reasoning is also orthogonal to the contemporary dialectic on the Acquaintance Principle (AP) for aesthetic judgements. ${ }^{18}$ Roughly speaking, the AP implies that aesthetic knowledge has to be acquired through an adequately specified relation of acquaintance between the perceiver and the object. In the previous argument, it is not necessary to maintain that our knowledge of the material in question is an element that has a direct bearing on the experience of the work in order for that material to be judged as aesthetically valuable. For example, if pressed on this point, we can adopt an anti-empiricist view of the value of architecture and argue that non-experiential features of a work are also relevant for its evaluation. ${ }^{19}$ In our case, we can say that the technical achievements of an architect in constructing a building are themselves an architectural value. My point is that the (non-spatial) importance of the material for the architectural value of a building can be supported either (1) by assuming that our knowledge of the significance of the material influences our aesthetic experience and that aesthetic judgments should be based on an adequately qualified acquaintance with the object of experience or (2) by adopting an anti-empiricist view of the value of architecture. According to this latter position, the significance of the material does not have to be relevant for the experience of the work in order to be considered as valuable.

Zevi may reply that the objection presupposes that the architectural value of a building is influenced by considerations related to the material employed and that this presupposition has not received sufficient justification. However, it seems highly plausible that the choice of different materials by the architect (or the engineers) affects our architectural 
experience and judgements of value on buildings (whether directly perceived or not) and that this is not related only to its spatial effects. In support of this view, it must be remembered that architecture is influenced greatly by the evolution of technology, and that one way of appreciating a building as a work of art is to evaluate the way in which certain technological solutions have been applied to practical and aesthetic problems. Besides, knowledge of materials and their use is considered an important skill that is necessary for the formation of architects. For example, the ability and skill displayed by Ludwig Mies van der Rohe in choosing and combining the materials for the construction of the Seagram Building is widely considered an architectural merit. ${ }^{20}$

Another objection raised by Scruton to the possibility of reducing architectural experience to spatial experience is based on the distinction between carved and modelled form. Scruton suggests that Leon Battista Alberti's Tempio Malatestiano in Rimini is beautiful from an architectural point of view, not only because of the rhythm of the arcade, but also in virtue of 'the quality of workmanship which can be seen in its finely sculpted lines'. ${ }^{21}$ If Agostino di Duccio's and Matteo de' Pasti's fine decorations were moulded into concrete, they would lose much of their capacity to elicit emotive responses and, as a result, our experience of the building would change. Zevi can reply to this objection by saying that these details, along with the gargoyles that adorn the Notre Dame de Paris cathedral or the sculptures of mythical tiger-headed fish on the Himeji Castle (姫路城), are certainly to be taken as artistically valuable, but they are not part of the architectural value of the buildings in which they are located. In particular, they may increase the overall artistic value of the building in virtue of their inner qualities as sculptures, but they are not to be considered as architectural elements. However, Zevi's observation presupposes the definition of the essence of architecture which is in question. In particular, Zevi's remarks simply remind us that architecture deals essentially with internal space and that all those other features that do not play a role in determining spatial effect may increase the artistic value of a building but not its architectural merits.

To convince a spatial theorist of architecture that her theory is not persuasive regarding the lack of architectural merit of decorative elements, we may appeal to a distinction between intrinsic and extrinsic ornamentation. Intuitively, there seems to be a distinction between at least two kinds of ornamentation in works of architecture. While we think that some of the decorative elements inside a building are relevant or important to its appreciation, we do not think that all are. For in- 
stance, we do not think that the Uffizi Gallery in Florence is architecturally more valuable in virtue of the masterpieces that hang on its walls. Botticelli's La Primavera or Titian's Venus of Urbino are extrinsic decorations of the internal space of the Uffizi. In contrast, the cortile (internal courtyard) of the building is articulated through a Doric order that some architectural historians, such as Giedion, judge to result in a 'masterpiece of perspective in depth'. ${ }^{22}$ Similarly, the statues that fill the niches in the piers contribute to the creation of the atmosphere that surrounds the gallery. Removing these statues would certainly change one's architectural experience of the building. These details, in contrast to the paintings hanging on the walls, are better seen as elements that are intrinsic to the architectural composition..$^{23}$ It may be thus argued that, if we adopt DZ, we cannot formulate a proper distinction between intrinsic and extrinsic ornamentation because, on the view expressed by DZ, every sculptural detail is external and thus not an architectural element (unless it provides a spatial effect). If this is the case, then, in adopting DZ, we lose the theoretical possibility of describing a series of interesting architectural features, a possibility that seems to clarify our understanding of certain buildings.

Scruton also advances an objection to the spatial idiom in architectural criticism: he claims that the concept of space can be eliminated from most critical writings without substantially modifying their content. ${ }^{24}$ Scruton rewrites two passages of Paul Frankl's Principles of Architectural History in such a way that the notion of space is eliminated without loss of content. ${ }^{25}$ However, Scruton does not provide a systematic way of replacing the notion of space. In some cases, such a demand may be too severe. However, in this case it seems fair, given the extensive use of the notion of space in recent architectural criticism. Nevertheless, even if all spatial idioms can be replaced by text that does not refer to space, it seems too strong to demand that they should be so replaced. After all, even if not fundamental or essential, descriptions in terms of spatial effects are important for the understanding of the role of certain details. ${ }^{26}$

DZ, with its related cluster of aesthetic concepts, does not adequately take into account other aspects that are usually taken as being essential to architecture as an art. One of them is the notion of a function that is independent of spatial considerations. ${ }^{27} \mathrm{~A}$ building that fails to operate under certain functional constraints, for example a house in which it is impossible to live, is an architectural failure. ${ }^{28}$ This suggestion is widely shared by many other architectural theorists and philosophers, even by those who do not take functional constraints as the sole criterion by 
which to evaluate a building from an architectural point of view. In addition, functional constraints are usually taken as being characterising elements of architecture, because they are generally considered crucial for distinguishing architecture from, for example, sculpture. Function is an essential element but not exclusive or unique: architectural success and value cannot be understood as merely a matter of satisfying a function. Given the foregoing, we may wonder whether functional aspects that are not restricted to space can be somehow vindicated in DZ by reducing them to spatial effects. Is it plausible to maintain that all functional constraints should be seen in terms of their spatial effects? I think not; in fact, the opposite view is true for a great part of the built environment: frequently we can understand the spatial effects of a building in virtue of our knowledge of its function, but not the other way round. For instance, we can make sense of the spatial arrangement of a church and the emphasis that is usually put on the position of the altar in virtue of the function of churches as places in which a ceremony is performed. This ceremony (a non-spatial function) requires that the attention of the worshippers converges on a specific point. A spatial effect that invites or suggests movement towards the altar is better understood in virtue of its (non-spatial) function, not the other way round. If this is the case, the primacy of space for architectural understanding is, again, seriously threatened. ${ }^{29}$

Another objection to DZ is that the related notion of architectural success cannot be evaluated solely in terms of internal space. Buildings that do not show any understanding of the environment in which they are built are more likely to be considered architectural failures (and conversely, showing an understanding of the surrounding environment is generally considered a good-making feature of a building). This does not mean that buildings must always harmonize with what surrounds them; certain buildings have been built in certain areas precisely with the aim of creating a contrast with a specific context. Think of buildings such as the modern complex of Langham Place in Mong Kok, Hong Kong. Langham Place was built in an area surrounded with old edifices of dubious aesthetic value with the precise aim of creating a contrast with the built environment and possibly increasing the value of the area through its presence. The good-making feature at issue is thus that a building should display an understanding of the environment in which it is located. Zevi's account cannot accommodate this idea because he understands architectural success solely in terms of internal space. ${ }^{30}$ 


\section{Conclusions}

In the preceding sections, I presented and evaluated various criticisms against the view that the essence of architecture is internal space. I concluded that the architectural value of a building should not be limited to its internal spatial effects because the value of other elements, such as (non-spatial) function, materials, ornamentation, and so on cannot all be reduced to spatial values. As a consequence, the interconnected network of definitions of some of the key concepts in the aesthetics of architecture should be correspondingly revised in order to take into account the complexity of architectural art.

\section{Notes}

1. The long list includes Heinrich Wölfflin, Renaissance und Barock (1888), trans. Kathrin Simon as Renaissance and Baroque (London: Collins, 1964); Principles of Art History (New York: Dover Publications, 1932); Paul Frankl, Principles of Architectural History, trans. J. F. O'Gorman (Cambridge, MA: The MIT Press, 1968); Henry Focillon, Vie des Forms (1934), trans. Charles Hogan as The Life of Forms in Art (New York: Zone Books, 1989); Sigfried Giedion, Space, Time and Architecture, $5^{\text {th }}$ edition (Cambridge, MA: Harvard University Press, 1941/1966); Bruno Zevi, Saper vedere l'architettura (Turin: Einaudi, 1948), trans. Milton Gendel as Architecture as Space: How to Look at Architecture (New York: Horizon Press, 1957), Susan Langer, Feeling and Form (Englewood Cliffs. NJ: Prentice Hall, 1957); Simon Unwin, Analysing Architecture (London: Routledge, 2003); and many others. See Filip Mattens, 'The Aesthetics of Space: Modern Architecture and Photography', Journal of Aesthetics and Art Criticism 69, no. 1 (2011), pp. 105-6, for further references.

2. See Maurice Lagueux, 'Ethics versus Aesthetics in Architecture', The Philosophical Forum 35, no. 2 (2004), pp.117-33, at p. 117.

3. See the writings of the architects Rudolph Schindler and Theo Van Doesburg in, respectively, David Gebhard, Rudolph Schindler (New York: Viking, 1971) and Allan Doig, Theo Van Doesburg: Painting into Architecture, Theory into Practice (Cambridge: Cambridge University Press, 2010).

4. Frank Lloyd Wright famously maintained that 'I thought I had "discovered" [...] this idea of the internal space being the reality of the building [...]'. See his 'The Destruction of the Box', a lecture delivered in New York in 1952 and collected in An American Architecture, ed. Edgar Kaufmann (New York: Horizon Press, 1955), pp. 75-78. For a discussion, see Allen H. Brooks, 'Wright and the Destruction of the Box', Journal of the Society of Architectural Historians 38 (1979), pp. 7-14. Wright relates his view that the reality of a building coincides with 
its enclosed space to Tenshin Okakura's discussion of the tea ceremony, which borrows, in turn, the philosophical Taoist conception of the Void. See Kevin Nute, Frank Lloyd Wright and Japan (London: Routledge, 2000), at p.122; Arata Isozaki, Japan-ness in Architecture (Cambridge, MA: The MIT Press, 2006), p. 5; Gail Satler, 'The Architecture of Frank Lloyd Wright: A Global View', in Journal of Architectural Education 53, no. 1 (1999), pp. 15-24 for an assessment of the relation between Wright's conception of space and Japanese and Chinese Aesthetics.

5. Scruton, The Aesthetics of Architecture, p. 44.

6. See Zevi, Architecture as Space, p. 30.

7. See Sigfried Giedion, Space, Time and Architecture, pp. lv-lvi.

8. Paul Zucker convincingly argued that the notion of space at issue in, for example, Braque and Gropius are not identical. See his 'The Aesthetics of Space in Architecture, Sculpture, and City Planning', The Journal of Aesthetics and Art Criticism 4, no. 1 (1945), pp. 12-19.

9. Giedion, Space, Time and Architecture, p. 436.

10. This thought is more humbly suggested in Stein Eiler Rasmussen, Experiencing Architecture (Cambridge, MA: The MIT Press, 1959/1962), pp. 9-34. The Japanese architect Arata Isozaki expressed the same idea in the following succinct way: 'space appears only in the time that humans perceive', see his Japanness in Architecture, p. 89.

11. 'Spatial interpretation does not compete with other interpretations, because it does not operate on the same plane. It is a super-interpretation, or, if you wish, an underlying interpretation.' Zevi, Architecture as Space, p. 222.

12. This process of creation of spaces through forms is analysed brilliantly in Francis K. Ching, Architecture: Form, Space \& Order. 3rd Edition (Hoboken, NJ: John Wiley \& Sons, 2007). In particular, Ching claims that ' $\mathrm{t}$ ] he form and enclosure of each space in a building either determines, or is determined by the form of the space around it. In a building, such as the theatre in Seinajoki, by Alvar Aalto, we can see several categories of spatial forms and analyze how they interact. Each category has an active or passive role in defining space. Some spaces, such as offices, have specific but similar functions and can be grouped into single linear or clustered.'

13. Zevi, Architecture as Space, p. 28. Zevi considers constructions that lack internal space (bridges, obelisks, fountains, arches, and so on) as not being works of architecture.

14. Zevi, Architecture as Space, p. 32.

15. The connection between architectural and spatial value is noted also in Geoffrey Scott, The Architecture of Humanism. 2nd Edition. (Garden City, NY: Doubleday Anchor Books, 1954), pp. 168-71. However, Scott does not take spatial value as the ultimate value of architecture. On the contrary, he understands it in 
terms of its effects on the perceiver: in many passages, Scott seems to introduce the notion of the spatial value of a building only to reduce it to the value of the effects of these limitations on perceivers. Unfortunately, Zevi does not clarify his notion of spatial value.

16. Scruton, The Aesthetics of Architecture, p. 44. Here, Scruton is simply exploring the view that architectural success is to be understood in terms of space; he is not endorsing it.

17. See, for instance, Nelson Goodman, Languages of Art (Indianapolis, IN: Bobbs-Merrill, 1968); Kendall Walton, 'Categories of Art', Philosophical Review 79 (1970), pp. 334-67; Arthur Danto, The Transfiguration of the Common Place (Cambridge, MA: Harvard University Press, 1981); Malcolm Budd, Values of Art (Harmondsworth: Penguin, 1995); and Matthew Kieran, 'Value of Art', in Routledge Companion to Aesthetics, eds. Berys Gaut and Dominic Lopes, 2nd edition (London: Routledge, 2005).

18. See Paisley Livingston, 'On an Apparent Truism in Aesthetics', British Journal of Aesthetics 43, no. 3 (2003), pp. 260-78; and Malcolm Budd, 'The Acquaintance Principle', British Journal of Aesthetics 43, no. 4 (2003), pp. 386-92 for recent discussion.

19. Anti-empiricism in the evaluation of art has been recently defended by David Davies in his 'Against Enlightened Empiricism', in Contemporary Debates in Aesthetics and the Philosophy of Art, ed. Matthew Kieran (Oxford: Blackwell, 2006), pp. 22-34.

20. It has to be said that in works of architecture, the inherent complexity of the process of construction and design requires the work and knowledge of many people. Architects and engineers frequently share the credit equally for the final result of their work. See Gyula Sebestyen, Construction: Craft to Industry (London: Routledge, 1998) for an account of the changing situation in the construction activity. See Franz Schulze, Mies Van der Rohe: A Critical Biography (University of Chicago Press, 1995), pp. 239-87 for details on the 'steel and glass' period of Mies.

21. Scruton, The Aesthetics of Architecture, p. 47.

22. Giedion, Space, Time and Architecture, p. 58.

23. Scruton holds a view that is similar in some respects to that which I have just sketched. Echoing Alberti, he claims that 'each part [detail] must be bound to the others in some relation of 'appropriateness', a relation which enables us to see the existence of one part as providing a reason for the existence of another.' Scruton, The Aesthetics of Architecture, p. 225. We can say that a detail or ornamental element is intrinsic if it is appropriate (in the sense just specified). However, it is not necessary for an external ornament to be inappropriate: for instance, we may treat a sculpture on the courtyard of a building as appropriate 
to the related building without, for this same reason, it also being an intrinsic ornamental element.

24. Scruton, The Aesthetics of Architecture, pp. 48-50.

25. Paul Frankl, Principles of Architectural History, trans. J. F. O'Gorman (Cambridge, MA: The MIT Press, 1968).

26. It is not just art critics who employ the spatial idiom; philosophers of architecture also use it. For instance, Rafael De Clercq has recently attempted to clarify the concept of harmony (between buildings) by using the notion of 'spatial proximity', a concept that resembles Zevi's concept of external space. See Rafael De Clercq, 'Modern Architecture and the Concept of Harmony', British Journal of Aesthetics 51, no. 1 (2011), pp. 69-79.

27. See Louis Mumford, 'Function and Expression in Architecture', Architectural Record 110 (1951), pp. 106-12; Rudolf Arnheim, 'From Function to Expression', The Journal of Aesthetics and Art Criticism 23, no. 1 (1964), pp. 29-41; Gordon Graham, 'Art and Architecture', British Journal of Aesthetics 29, no. 3 (1989), pp. 248-57; Philosophy of the Arts, 2nd Edition (London and New York: Routledge, 1997/2000), pp. 137-54; Allen Carlson, 'Existence, Location, and Function: The Appreciation of Architecture', in Philosophy of Architecture, ed. M. Mitias (Amsterdam: Editions Rodopi, 1994), pp. 141-64. Leaving aside famous slogans in favour of a purely functionalist approach to architecture by well-known modern architects, such as Louis Sullivan ('form follows function'), Ludwig Mies van der Rohe ('less is more') and Le Corbusier ('The house is a machine for living in'), function has also been recognised as a central feature of architecture by architects from completely different styles, such as Augustus Welby Pugin. See Scruton, The Aesthetics of Architecture, pp. 38-43; and Allen Carlson and Glenn Parsons, Functional Beauty (Oxford: Oxford University Press, 2008), 137-66; for critical discussions of these ideas.

28. See Graham, Philosophy of the Arts, p. 139 for similar considerations.

29. Unqualified function and space are not necessarily in contrast: we can understand Zevi's theory as claiming that the only proper architectural function is spatial. The spatial theorist would then have to show that all the other possible architectural functions can be reduced to spatial function. However, this seems highly counterintuitive.

30. See Allen Carlson, 'Existence, Location, and Function: The Appreciation of Architecture', in Philosophy of Architecture, ed. M. Mitias (Amsterdam: Rodopi, 1994), pp. 141-64 for a discussion of the role of location in architecture. 